\title{
Antiviral Active Compounds Derived from Natural Sources against Herpes Simplex Viruses
}

\author{
Lukas van de Sand ${ }^{1,+}+$, , Maren Bormann ${ }^{1,+}{ }^{-}$, Yasmin Schmitz ${ }^{2}$, Christiane Silke Heilingloh ${ }^{1}$, Oliver Witzke ${ }^{1}$ \\ and Adalbert Krawczyk 1,2,*D \\ 1 West German Centre of Infectious Diseases, Department of Infectious Diseases, University Hospital Essen, \\ University of Duisburg-Essen, 45147 Essen, Germany; lukas.vandesand@uk-essen.de (L.v.d.S.); \\ maren.bormann@uk-essen.de (M.B.); christiane.heilingloh@uk-essen.de (C.S.H.); \\ oliver.witzke@uk-essen.de (O.W.) \\ 2 Institute of Virology, University Hospital Essen, University of Duisburg-Essen, 45147 Essen, Germany; \\ yasmin.schmitz@stud.uni-due.de \\ * Correspondence: adalbert.krawczyk@uni-due.de \\ + These authors contributed equally to this work.
}

Citation: van de Sand, L.;

Bormann, M.; Schmitz, Y.;

Heilingloh, C.S.; Witzke, O.;

Krawczyk, A. Antiviral Active Compounds Derived from Natural Sources against Herpes Simplex

Viruses. Viruses 2021, 13, 1386.

https://doi.org/10.3390/v13071386

Academic Editor: Barry J. Margulies

Received: 12 June 2021

Accepted: 14 July 2021

Published: 16 July 2021

Publisher's Note: MDPI stays neutral with regard to jurisdictional claims in published maps and institutional affiliations.

Copyright: (c) 2021 by the authors. Licensee MDPI, Basel, Switzerland. This article is an open access article distributed under the terms and conditions of the Creative Commons Attribution (CC BY) license (https:// creativecommons.org/licenses/by/ $4.0 /)$.

\begin{abstract}
Herpes simplex viruses (HSV) are ubiquitously distributed with a seroprevalence ranging up to $95 \%$ in the adult population. Refractory viral infections with herpes simplex virus type 1 (HSV-1) and type 2 (HSV-2) represent a major global health issue. In particular, the increasing occurrence of resistance to conventional antiviral drugs make the therapy of such infections even more challenging. For instance, the frequent and long-term use of acyclovir and other nucleoside analogues targeting the viral DNA-polymerase enhance the development of resistant viruses. Particularly, the incidental increase of those strains in immunocompromised patients is alarming and represent a major health concern. Alternative treatment concepts are clearly needed. Natural products such as herbal medicines showed antiherpetic activity in vitro and in vivo and proved to be an excellent source for the discovery and isolation of novel antivirals. By this means, numerous plant-derived compounds with antiviral or antimicrobial activity could be isolated. Natural medicines and their ingredients are well-tolerated and could be a good alternative for treating herpes simplex virus infections. This review provides an overview of the recent status of natural sources such as plants, bacteria, fungi, and their ingredients with antiviral activity against herpes simplex viruses. Furthermore, we highlight the most potent herbal medicines and ingredients as promising candidates for clinical investigation and give an overview about the most important drug classes along with their potential antiviral mechanisms. The content of this review is based on articles that were published between 1996 and 2021.
\end{abstract}

Keywords: herpes simplex viruses; natural products; antiherpetic drugs; resistance

\section{Introduction}

Herpes simplex virus infections are considered a major public health issue worldwide. These human pathogen DNA viruses belong to the family of Alphaherpesvirinae. Upon primary infection, the herpes simplex viruses type 1 and 2 (HSV-1 and HSV-2) persist lifelong in the autonomic and sensory ganglia of its host. Especially HSV-1 infections are ubiquitously distributed with a seroprevalence ranging up to $95 \%$ in the adult population [1]. After reactivation, HSV may cause symptoms ranging from painful, but self-limited infections of the oral or genital mucosa to severe infections of the eye or life-threatening infections in immunocompromised hosts or newborns [2,3]. Active HSV-1 infections are usually associated with oral or facial herpes, while HSV-2 predominately causes genital infections. Reactivated HSV-2 infections often exhibit painful genital lesions providing a higher risk for other sexually transmitted diseases and invasive cervical carcinoma [4]. 
Although numerous vaccine candidates have been investigated in clinical trials, there is no licensed vaccine available for the prevention of HSV infections. Over the last decades, many different antiviral drugs targeting the viral DNA-polymerase were approved for the treatment of acute HSV infections. The most widely used antiviral agents against HSV are acyclovir (ACV), valacyclovir, famciclovir, cidofovir, and foscarnet. ACV and the related nucleoside analogues can successfully inhibit viral replication and thereby mediate cure from HSV-related symptoms, but the emergence of drug resistance to ACV has created a barrier for the treatment of HSV infections [5]. Moreover, it has been demonstrated that ACV therapy in HIV/HSV-co-infected patients reduces HIV serum levels and may protract the necessity of an antiretroviral therapy [6-8]. However, ACV may interact directly with the HIV reverse transcriptase in HIV-infected cells, which may increase the occurrence of the reverse transcriptase mutants that are associated with a reduced sensitivity of the virus to antiretroviral therapy $[9,10]$. Furthermore, corneal morbidity and blindness are common issues of ACV-refractory HSV infections of the cornea in industrial nations [11]. ACVresistant infections are frequently observed in immunocompromised patients. Due to a long-term prophylactic or pre-emptive antiviral treatment in these patients, the occurrence of ACV resistance is particularly high in this group [12]. In the average adult population, the frequency of ACV-resistant HSV was determined with $0.27 \%(n=368)$ [12]. In contrast, the frequency of ACV-resistant HSV was assessed with 7.03\% in immunocompromised patients [12]. The highest rates of ACV resistance were reported in patients undergoing hematopoietic stem cell transplantation (14.3\%), followed by HIV-infected patients (3.92\%) or patients suffering from various tumor diseases (3.85\%) [12]. Cross-resistance to other nucleoside analogs targeting the viral HSV thymidine kinase (TK) are frequent, since a reduced sensitivity of HSV to ACV is mostly caused by mutations in the TK gene $[5,13]$. However, resistance not only emerges against drugs such as famciclovir or penciclovir that target HSV-TK but also against the viral DNA-polymerase inhibitors foscarnet and cidofovir [14], the latter severely in patients undergoing stem cell transplantation [12]. DNA-polymerase inhibitors can be used for the treatment of ACV-resistant HSV infections. However, their use is limited due to possible serious side effects, especially in patients with comorbidities [5].

Clearly, there is an urgent need to explore new effective and well-tolerated approaches for the treatment of HSV infections and reactivations. Traditional herbal medicines are an abundant source of antimicrobial or antiviral active substances. Plant extracts and other natural products have been used for hundreds of years for the treatment of infectious diseases. We screened the PubMed database to find relevant articles by using the keywords natural products, medicinal plants, medicinal herbs, herbal medicine, plant oils, herpes simplex virus, herpes labialis, and herpes genitalis. Articles included in our analysis were published from 1996 to 2021. We searched for studies that described compounds that were isolated from natural sources such as plants, fungi, and other sources. We focused on wellcharacterized compounds with already uncovered mechanisms of how these compounds interfere with the viral replication. This strategy allows for conclusions about the potential antiviral activity of these compounds against ACV-resistant viruses. The review gives an overview of the distinct compounds isolated from plants and other natural sources and summarizes the results from in vitro and in vivo studies conducted thus far.

\section{Antiviral Active Ingredients from Natural Sources}

Herbal medicines have been used for centuries to treat infectious diseases. Within the last decades, numerous compounds with antiviral activity against HSV and other viruses could be isolated from distinct natural sources such as plants or fungi. The antiviral active ingredients include alkaloids, terpenes, polysaccharides, flavonoids, phenolic acids, and steroids (Figure 1). The compounds inhibit the viral replication by using different mechanisms, which are summarized in Figure 2 and Table 1 and described below in more detail. 


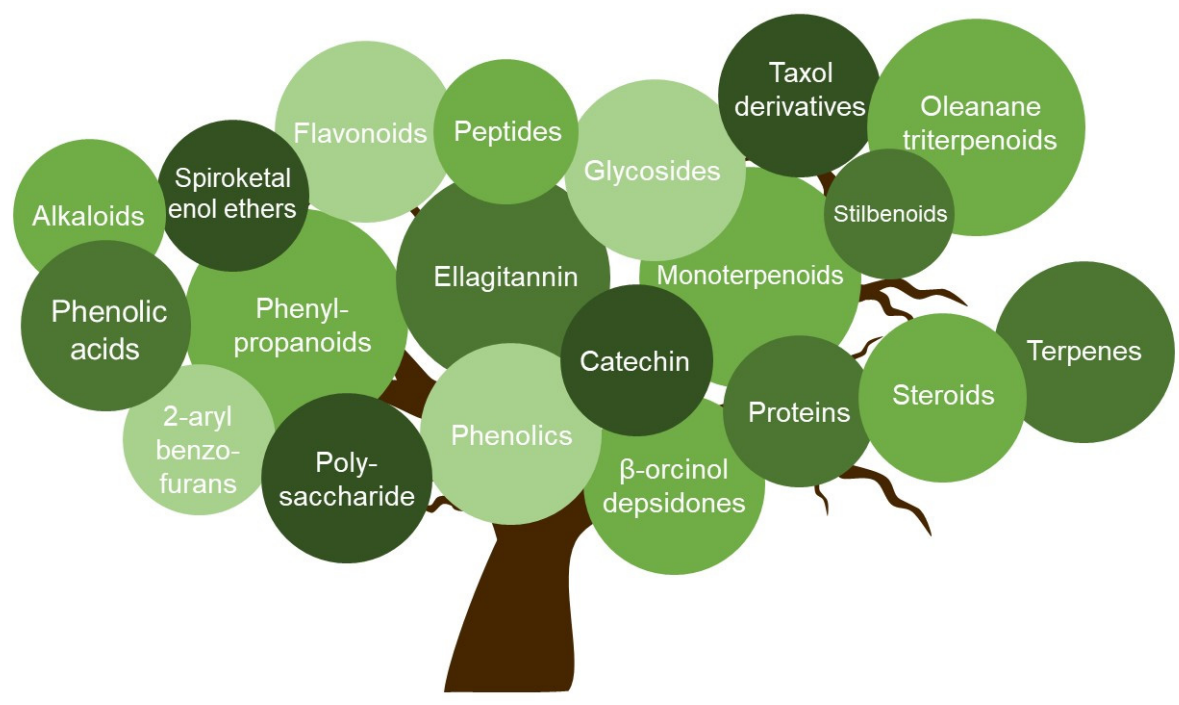

Figure 1. Classification of antiherpetic agents derived from natural sources. Natural sources such as plants or fungi are rich in different groups of bioactive compounds. Several of these groups (e.g., alkaloids, terpenes, polysaccharides, flavonoids, phenolic acids, and steroids) were identified as antiviral active agents against HSV-1 and HSV-2. 


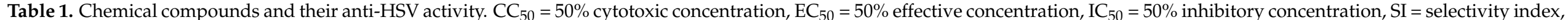

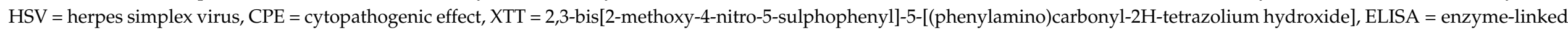

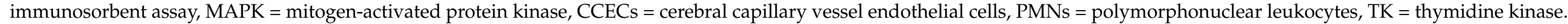

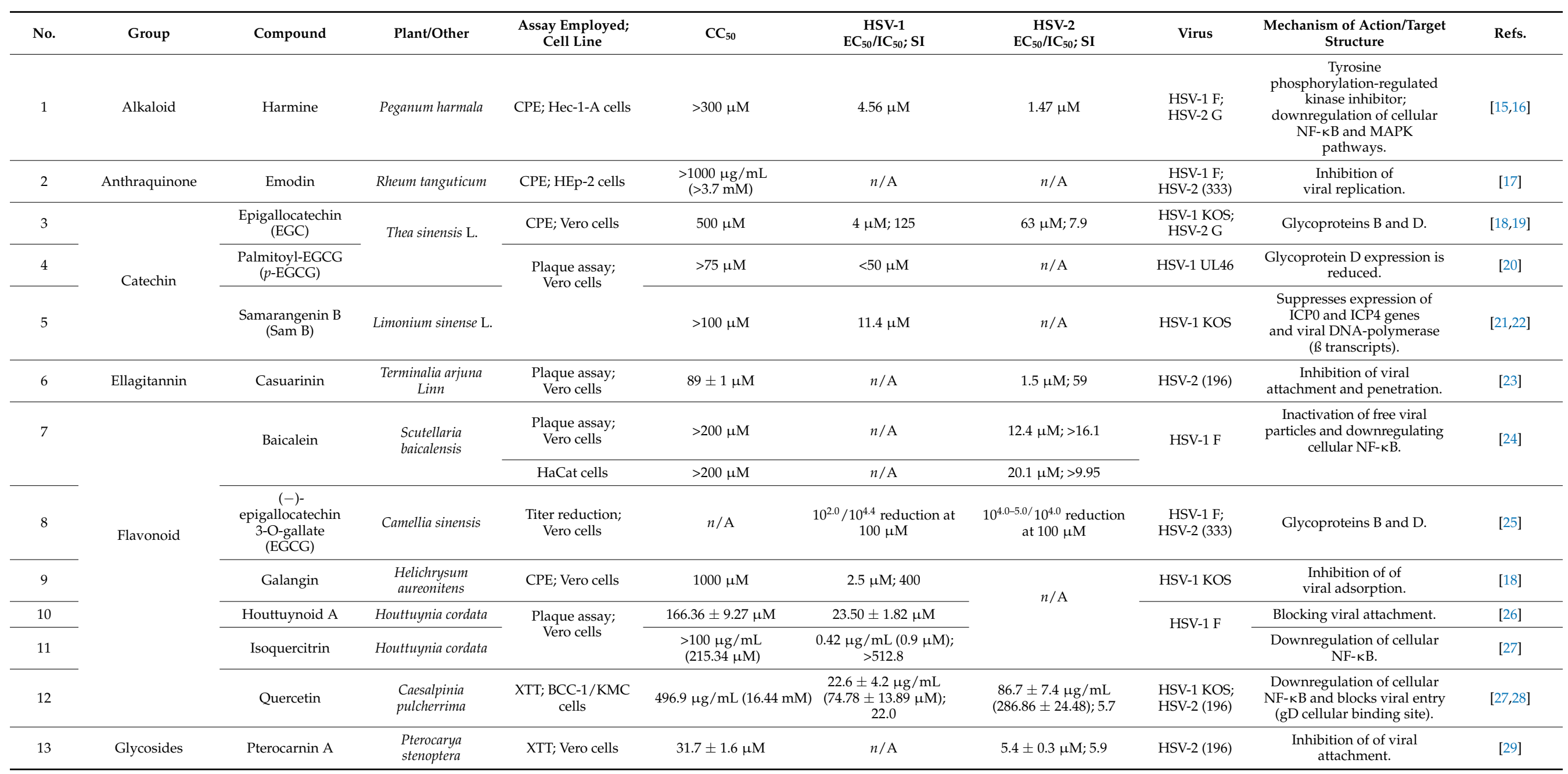


Table 1. Cont.

\begin{tabular}{|c|c|c|c|c|c|c|c|c|c|c|}
\hline No. & Group & Compound & Plant/Other & $\begin{array}{l}\text { Assay Employed; } \\
\text { Cell Line }\end{array}$ & $\mathrm{CC}_{50}$ & $\begin{array}{c}\mathrm{HSV}-1 \\
\mathrm{EC}_{50} / \mathrm{IC}_{50} ; \mathrm{SI}\end{array}$ & $\begin{array}{c}\mathrm{HSV-2} \\
\mathrm{EC}_{50} / \mathrm{IC}_{50} ; \mathrm{SI}\end{array}$ & Virus & $\begin{array}{l}\text { Mechanism of Action/Target } \\
\text { Structure }\end{array}$ & Refs. \\
\hline 14 & Harmaline & $\begin{array}{l}\text { 7-methoxy-1- } \\
\text { methyl-4,9- } \\
\text { dihydro-3H- } \\
\text { pyrido[3,4- } \\
\text { b]indole } \\
\text { (HM) }\end{array}$ & $\begin{array}{c}\text { Ophiorrhiza } \\
\text { nicobarica Balkr }\end{array}$ & $\begin{array}{l}\text { Plague assay; } \\
\text { Vero cells }\end{array}$ & $\begin{array}{c}30 \mu \mathrm{g} / \mathrm{mL}(120.14 \\
\mu \mathrm{M})\end{array}$ & $\begin{array}{c}1.1 \pm 0.1 \mu \mathrm{g} / \mathrm{mL} \\
(4.41 \pm 0.4 \mu \mathrm{M}) ; 27.27\end{array}$ & $\begin{array}{c}1.5 \pm 0.1 \mu \mathrm{g} / \mathrm{mL} \\
(6.01 \pm 0.4 \mu \mathrm{M}) ; 20\end{array}$ & $\begin{array}{l}\text { HSV-1 F; } \\
\text { HSV-2 G }\end{array}$ & $\begin{array}{l}\text { Suppression of viral } \\
\text { immediate early } \\
\text { gene expression. }\end{array}$ & {$[30,31]$} \\
\hline 15 & Monoterpenoid & Geraniol & Thymus bovei & $\begin{array}{l}\text { Titer reduction; } \\
\text { Vero cells }\end{array}$ & $\begin{array}{l}>210 \mu \mathrm{g} / \mathrm{mL} \\
(1361.42 \mu \mathrm{M})\end{array}$ & $n / \mathrm{A}$ & $\begin{array}{l}1.92 \pm 0.84 \mu \mathrm{g} / \mathrm{mL} \\
(12.45 \pm 5.45 \mu \mathrm{M}) \\
\quad>109.38\end{array}$ & HSV-2 & $\begin{array}{l}\text { In silico: Interacts with } \\
\text { HSV-2 protease. }\end{array}$ & [32] \\
\hline 17 & \multirow[t]{2}{*}{$\begin{array}{l}\text { Oleanane } \\
\text { triterpenoid }\end{array}$} & $\begin{array}{l}\text { Glycyrrhetinic } \\
\text { acid }\end{array}$ & \multirow[t]{2}{*}{ Glycyrrhiza glabra } & \multirow{2}{*}{$\begin{array}{l}\text { Plaque assay; } \\
\text { Vero cells }\end{array}$} & $84.0 \pm 2.8 \mu \mathrm{M}$ & $21.7 \pm 0.6 \mu \mathrm{M} ; 3.9$ & \multirow[t]{2}{*}{$n / \mathrm{A}$} & \multirow{2}{*}{ HSV-1 KOS } & $\begin{array}{l}\text { Induces the autophagy } \\
\text { activator Beclin } 1 \rightarrow \text { blocks } \\
\text { HSV replication. }\end{array}$ & [33] \\
\hline 18 & & Glycyrrhizin & & & $>608 \mu \mathrm{M}$ & $\begin{array}{c}225 \pm 24.1 \mu \mathrm{M} / \mathrm{mL} ; \\
>2.7\end{array}$ & & & $\begin{array}{c}\text { Reduces adhesion force } \\
\text { between CCECs and PMNs. }\end{array}$ & {$[33,34]$} \\
\hline 19 & Phenolic acid & Chebulinic acid & Terminalia chebula & $\begin{array}{l}\text { Plaque assay; } \\
\text { Vero cells }\end{array}$ & $>200 \mu \mathrm{g} / \mathrm{mL}$ & $17.02 \pm 2.82 \mu \mathrm{M} ; 18.62$ & $0.06 \pm 0.002 \mu \mathrm{g} / \mathrm{mL}$ & $\begin{array}{l}\text { HSV-1 KOS; } \\
\text { HSV-2 G }\end{array}$ & $\begin{array}{l}\text { Prevention of HSV-1 } \\
\text { glycoprotein-mediated cell } \\
\text { fusion events and } \\
\text { attachment of HSV-2. }\end{array}$ & {$[35,36]$} \\
\hline 21 & Phenolic & Curcumin & $\begin{array}{l}\text { The curry spice } \\
\text { turmeric }\end{array}$ & CPE; Vero cells & $\begin{array}{l}49.8 \pm 0.4 \mu \mathrm{g} / \mathrm{mL} \\
(135.18 \pm 1.09 \mu \mathrm{M})\end{array}$ & $n / \mathrm{A}$ & $n / \mathrm{A}$ & HSV-1 (17) & $\begin{array}{l}\text { P300/CBP histone } \\
\text { acetyltransferase. }\end{array}$ & {$[39,40]$} \\
\hline 22 & Phenylpropanoid & Verbascoside & Lepechinia speciosa & $\begin{array}{l}\text { Plaque assay; } \\
\text { Vero cells }\end{array}$ & $>\underset{\mu \mathrm{M})}{>200 \mu \mathrm{g} / \mathrm{mL}(320.21}$ & $\begin{array}{c}58 \mu \mathrm{g} / \mathrm{mL}(92.86 \mu \mathrm{M}) \\
>3.4\end{array}$ & $\begin{array}{c}8.9 \mu \mathrm{g} / \mathrm{mL}(14.25 \mu \mathrm{M}) \\
>22.4\end{array}$ & $\begin{array}{l}\text { HSV-1; HSV-2 } \\
\quad \text { (clinical } \\
\text { isolates) }\end{array}$ & $\begin{array}{l}\text { HSV-1: prevention of viral } \\
\text { adsorption, intracellular } \\
\text { viral inhibition; HSV-2: } \\
\text { inhibition of attachment } \\
\text { and penetration. }\end{array}$ & [41] \\
\hline 23 & Polysaccharide & MI-S & $\begin{array}{c}\text { Agaricus } \\
\text { brasiliensis }\end{array}$ & $\begin{array}{l}\text { Plaque assay; } \\
\text { Vero cells }\end{array}$ & $\begin{array}{l}2415.29 \pm 389.21 \mu \mathrm{g} / \mathrm{mL} \\
(134.18 \pm 21.61 \mu \mathrm{M})\end{array}$ & $\begin{array}{c}1.24 \pm 0.05 \mu \mathrm{g} / \mathrm{mL} \\
(0.07 \mu \mathrm{M}), \\
1948 ; 5.50 \pm 0.58 \mu \mathrm{g} / \mathrm{mL} \\
(0.31 \pm 0.03 \mu \mathrm{M}), 439 \\
\text { (during; after infection) }\end{array}$ & $\begin{array}{c}0.39 \pm 0.17 \mu \mathrm{g} / \mathrm{mL} \\
(0.02 \pm 0.01 \mu \mathrm{M}), 6193 ; \\
4.30 \pm 0.36 \mu \mathrm{g} / \mathrm{mL} \\
(0.24 \pm 0.02 \mu \mathrm{M}), 562 \\
\text { (during; after infection) }\end{array}$ & $\begin{array}{l}\text { HSV-1 KOS; } \\
\text { HSV-2 } 333\end{array}$ & $\begin{array}{l}\text { Inhibition of attachment, } \\
\text { penetration and cell-to-cell } \\
\text { spread. }\end{array}$ & [42] \\
\hline
\end{tabular}


Table 1. Cont.

\begin{tabular}{|c|c|c|c|c|c|c|c|c|c|c|}
\hline No. & Group & Compound & Plant/Other & $\begin{array}{l}\text { Assay Employed; } \\
\text { Cell Line }\end{array}$ & $\mathrm{CC}_{50}$ & $\begin{array}{c}\mathrm{HSV}-1 \\
\mathrm{EC}_{50} / \mathrm{IC}_{50} ; \mathrm{SI}\end{array}$ & $\begin{array}{c}\mathrm{HSV}-2 \\
\mathrm{EC}_{50} / \mathrm{IC}_{50} ; \mathrm{SI}\end{array}$ & Virus & $\begin{array}{l}\text { Mechanism of Action/Target } \\
\text { Structure }\end{array}$ & Refs. \\
\hline 24 & \multirow[b]{2}{*}{$\begin{array}{l}\text { Spiroketal-enol } \\
\text { ether derivative }\end{array}$} & Scleroglucan & $\begin{array}{l}\text { Scierotium } \\
\text { glucanicum }\end{array}$ & CPE; Vero cells & $\begin{array}{l}400 \mu \mathrm{g} / \mathrm{mL} \\
(559.83 \mu \mathrm{M})\end{array}$ & $5 \mu \mathrm{g} / \mathrm{mL}(7 \mu \mathrm{M}) ; 80$ & $n / \mathrm{A}$ & HSV-1 F & $\begin{array}{c}\text { Glycoproteins of HSV-1 } \\
\text { (inhibits adsorption step). }\end{array}$ & [43] \\
\hline 25 & & $\begin{array}{l}\text { (E)-2-(2,4-hexa- } \\
\text { diynyliden)- } \\
\text { 1,6dioxaspiro[4.5] } \\
\text { dec-3-ene }\end{array}$ & Tanacetum vulgare & $\begin{array}{l}\text { Time-of-addition } \\
\text { assay; Vero cells }\end{array}$ & $\begin{array}{l}>30 \mu \mathrm{g} / \mathrm{mL} \\
(>149.83 \mu \mathrm{M})\end{array}$ & $\begin{array}{c}0.146 \pm 0.013 \mu \mathrm{g} / \mathrm{mL} \\
(0.73 \pm 0.06 \mu \mathrm{M}) ;>205\end{array}$ & $\begin{array}{c}0.127 \pm 0.009 \mu \mathrm{g} / \mathrm{mL} \\
(0.63 \pm 0.04 \mu \mathrm{M}) ;>236\end{array}$ & $\begin{array}{c}\text { HSV-1 } \\
\text { (AY240815.1); } \\
\text { HSV-2 } \\
\text { (HM011430.1) }\end{array}$ & $\begin{array}{l}\text { Suppression of viral RNA } \\
\text { synthesis. }\end{array}$ & [44] \\
\hline 26 & Steroid & Halistanol sulfate & Petromica citrina & $\begin{array}{l}\text { Plaque assay; } \\
\text { Vero cells }\end{array}$ & $\begin{array}{c}13.83 \pm 3.75 \mu \mathrm{g} / \mathrm{mL} \\
(20.08 \pm 5.44 \mu \mathrm{M})\end{array}$ & $\begin{array}{c}5.63 \pm 1.3 \mu \mathrm{g} / \mathrm{mL} \\
(8.17 \pm 1.89 \mu \mathrm{M}) ; 2.46\end{array}$ & $n / \mathrm{A}$ & HSV-1 KOS & $\begin{array}{l}\text { Inhibition of attachment and } \\
\text { penetration. Impairs HSV-1 } \\
\text { gD and ICP27 levels. }\end{array}$ & [45] \\
\hline 28 & $\begin{array}{l}\text { Stilbenoid and } \\
\text { 2-arylbenzofuran }\end{array}$ & Oxyresveratrol & Artocarpus lakoocha & $\begin{array}{l}\text { Plaque assay; } \\
\text { Vero cells }\end{array}$ & $>100 \mu \mathrm{M}$ & $63.5 \mu \mathrm{M}$ & $55.3 \mu \mathrm{M}$ & HSV-1; HSV-2 & $\begin{array}{l}\text { Inhibition of early and late } \\
\text { replication. }\end{array}$ & {$[47,48]$} \\
\hline 29 & Taxol derivative & $\begin{array}{c}n \text {-benzoyl- } \\
\left(2^{\prime} \mathrm{R}, 3^{\prime} \mathrm{S}\right)- \\
\text { 3'phenylisoserine }\end{array}$ & Lactarius & CPE; Vero cells & $>500 \mu \mathrm{g} / \mathrm{mL}$ & $\begin{array}{c}21.7 \mu \mathrm{g} / \mathrm{mL} \\
(76.06 \mu \mathrm{M}) ;>23\end{array}$ & $n / \mathrm{A}$ & $\begin{array}{c}\text { HSV-1 } \\
\text { (McIntyre) }\end{array}$ & $\begin{array}{l}\text { Inhibition of HSV-1 } \\
\text { replication (possibly related } \\
\text { to mitotic division). }\end{array}$ & [49] \\
\hline 30 & \multirow{4}{*}{ Terpene } & $\begin{array}{l}\text { 28-Deacetylsendanin } \\
\text { (28-DAS) }\end{array}$ & Melia azedarach & ELISA; Vero cells & $\begin{array}{l}>400 \mu \mathrm{g} / \mathrm{mL} \\
(696.11 \mu \mathrm{M})\end{array}$ & $1.46 \mu \mathrm{g} / \mathrm{mL}(2.54 \mu \mathrm{M})$ & \multirow{4}{*}{$n / \mathrm{A}$} & $\begin{array}{c}\text { HSV-1 } \\
\text { (McIntyre) }\end{array}$ & Reduces activity of TK. & {$[50]$} \\
\hline 31 & & Isoborneol & Salvia fruticosa & $\begin{array}{l}\text { Plaque assay; Vero } \\
\text { cells }\end{array}$ & $n / \mathrm{A}$ & $n / \mathrm{A}$ & & HSV-1 F & $\begin{array}{l}\text { Affected TK-independent } \\
\text { glycosylation process of viral } \\
\text { glycoproteins B and D. }\end{array}$ & {$[51]$} \\
\hline 32 & & $\begin{array}{l}\text { 1-cinnamoyl-3,11- } \\
\text { dihydroxymeliacarpin } \\
\text { (CDM) }\end{array}$ & Melia azedarach & $\begin{array}{l}\text { Plaque assay; } \\
\text { HCLE cells }\end{array}$ & $>100 \mu \mathrm{M}$ & $0.78 \mu \mathrm{M}$ & & HSV-1 KOS & $\begin{array}{c}\text { Inhibition of glycoproteins } \mathrm{B}, \\
\mathrm{gC}, \mathrm{gD} \text { intracellular } \\
\text { trafficking and } \\
\text { downregulates cellular } \\
\text { NF- } \mathrm{kB} \text {. }\end{array}$ & [52-54] \\
\hline 33 & & Triptofordin C-2 & $\begin{array}{l}\text { Tripterygium } \\
\text { wilfordii }\end{array}$ & $\begin{array}{l}\text { Plaque assay; } \\
\text { HeLa cells }\end{array}$ & $\begin{array}{c}89 \pm 9.5 \mu \mathrm{g} / \mathrm{mL} \\
(145.76 \pm 15.56 \mu \mathrm{M})\end{array}$ & $\begin{array}{c}3.7 \pm 0.90 \mu \mathrm{g} / \mathrm{mL} \\
(6.06 \pm 1.47 \mu \mathrm{M}) \\
24 \pm 3.2\end{array}$ & & HSV-1 HF & $\begin{array}{l}\text { Suppression of viral } \\
\text { immediate early } \\
\text { gene expression. }\end{array}$ & [55] \\
\hline
\end{tabular}


Table 1. Cont

\begin{tabular}{|c|c|c|c|c|c|c|c|c|c|c|}
\hline No. & Group & Compound & Plant/Other & $\begin{array}{l}\text { Assay Employed; } \\
\text { Cell Line }\end{array}$ & $\mathrm{CC}_{50}$ & $\begin{array}{c}\mathrm{HSV}-1 \\
\mathrm{EC}_{50} / \mathrm{IC}_{50} ; \mathrm{SI}\end{array}$ & $\begin{array}{c}\mathrm{HSV}-2 \\
\mathrm{EC}_{50} / \mathrm{IC}_{50} ; \mathrm{SI}\end{array}$ & Virus & $\begin{array}{l}\text { Mechanism of Action/Target } \\
\text { Structure }\end{array}$ & Refs. \\
\hline 34 & $\begin{array}{l}\beta \text {-orcinol } \\
\text { depsidone }\end{array}$ & Psoromic acid & Usnea & $\begin{array}{l}\text { Plaque assay; Vero } \\
\text { cells }\end{array}$ & $>310 \mu \mathrm{M}$ & $1.9 \pm 0.42 \mu \mathrm{M} ;>163.2$ & $2.7 \pm 0.43 \mu \mathrm{M} ; 114.8$ & $\begin{array}{l}\text { HSV-1 KOS; } \\
\text { HSV-2 (A234) }\end{array}$ & $\begin{array}{l}\text { Inhibition of HSV replication: } \\
\text { HSV-1 DNA-polymerase } \\
\text { in vitro; HSV-2 } \\
\text { DNA-polymerase in silico. }\end{array}$ & {$[56]$} \\
\hline 35 & \multirow{3}{*}{ Peptide } & Griffithsin & Griffithsia & $\begin{array}{l}\text { Plaque assay; } \\
\text { CaSki }\end{array}$ & no cytotoxic effect & $n / \mathrm{A}$ & $2.3 \mu \mathrm{g} / \mathrm{mL}(0.18 \mu \mathrm{M})$ & HSV-2 (333) & $\begin{array}{l}\text { Inhibition of viral attachment } \\
\text { (cell-to-cell spread). }\end{array}$ & [57] \\
\hline 36 & & Subtilosin & $\begin{array}{c}\text { Bacillus } \\
\text { amyloliquefaciens }\end{array}$ & $\begin{array}{l}\text { Plaque assay; Vero } \\
\text { cells }\end{array}$ & $\underset{\mu \mathrm{M})}{314 \mu \mathrm{g} / \mathrm{mL}(92.3}$ & $\begin{array}{c}9.6 \mu \mathrm{g} / \mathrm{mL}(2.82 \mu \mathrm{M}) \\
33\end{array}$ & $\begin{array}{c}18.2 \mu \mathrm{g} / \mathrm{mL}(5.35 \mu \mathrm{M}) ; \\
17.4\end{array}$ & $\begin{array}{l}\text { HSV-1 F; } \\
\text { HSV-2 G }\end{array}$ & $\begin{array}{l}\text { Late stages of the viral } \\
\text { replicative cycle and } \\
\text { intracellular glycoprotein } \\
\text { transport. }\end{array}$ & {$[58,59]$} \\
\hline 37 & & $\begin{array}{l}\text { Trichosanthin } \\
\text { (TCS) }\end{array}$ & $\begin{array}{l}\text { Trichosanthes } \\
\text { kirilowii }\end{array}$ & ELISA; Vero cells & $\begin{array}{c}416.5 \pm 34.5 \mu \mathrm{g} / \mathrm{mL} \\
(15.42 \pm 1.28 \mu \mathrm{M})\end{array}$ & $\begin{array}{c}38.4 \pm 17.5 \mu \mathrm{g} / \mathrm{mL} \\
(1.42 \pm 0.65 \mu \mathrm{M}) ; 10.8\end{array}$ & $n / \mathrm{A}$ & HSV-1 F & $\begin{array}{l}\text { Suppression of p38 MAPK } \\
\text { protein and Bcl-2 gene } \\
\text { activity, replication (E and L), } \\
\text { DNA expression and viral } \\
\text { release. }\end{array}$ & [60-62] \\
\hline
\end{tabular}


<smiles></smiles>

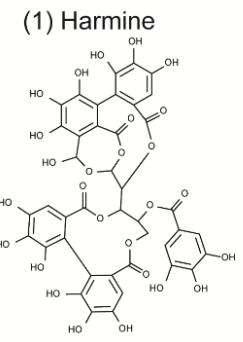

(6) Casuarinin
(2) Emodin<smiles></smiles>

(7) Baicalein
(3) Epigallocatechin<smiles>O=C(OC1Cc2c(O)cc(O)cc2OC1c1cc(O)c(O)c(O)c1)c1cccc(O)c1</smiles>

(8) (-)-epigallocatechin 3-O-gallate
(4) Palmitoyl-EGCG<smiles>O=c1c(O)c(-c2ccccc2)oc2cc(O)cc(O)c12</smiles>

(9) Galangin

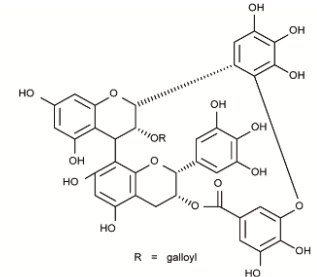

(5) Samarangenin $B$

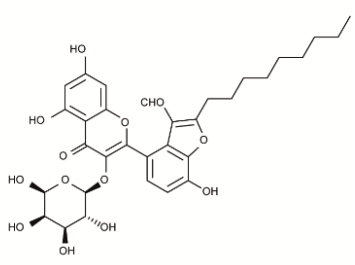

(10) Houttuynoid A

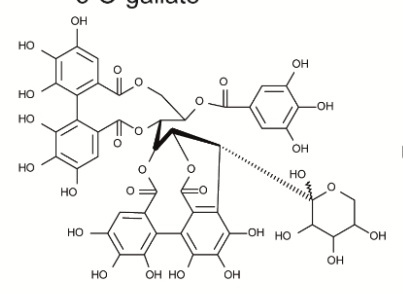

(13) Pterocarnin A

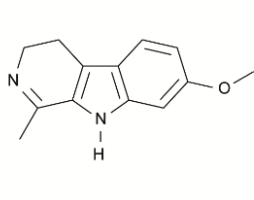

(14) 7-methoxy-1-methyl4,9-dihydro-3H-pyrido [3,4-b]indole<smiles>CC(C)=CCCC(C)=CCO</smiles>

(15) Geraniol

(11) Isoquercitrin

(12) Quercetin

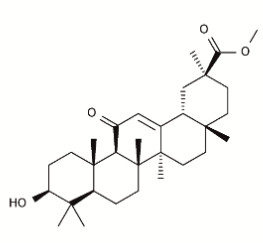

(16) Glycyrrhetic acid methylester

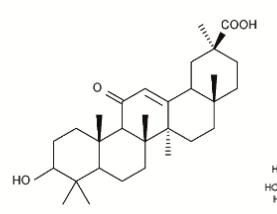

(17) Glycyrrhetinic acid

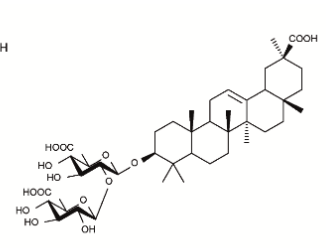

(18) Glycyrrhizin

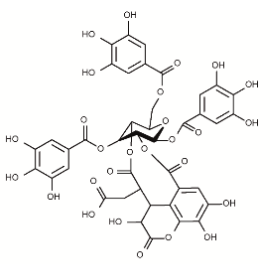

(19) Chebulinic acid

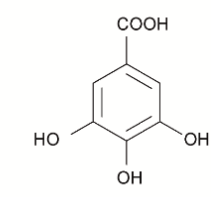

(20) Gallic acid<smiles>COc1cc(/C=C/C(=O)/C=C(O)/C=C/c2ccc(O)c(O)c2)ccc1O</smiles>

(21) Curcumin

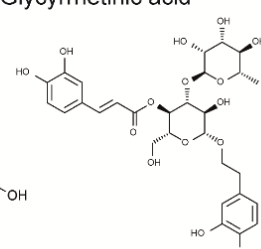

(22) Verbascoside

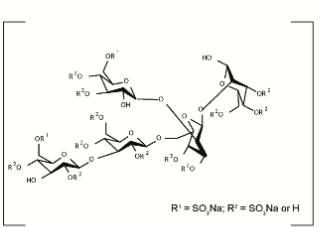

(23) MI-S

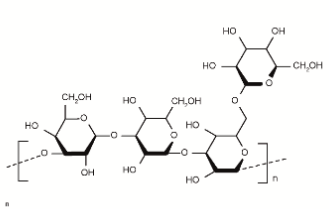

(24) Scleroglucan (25) (E)-2-(2,4-hexa-diynyliden)-1,6 dioxaspiro[4.5]dec-3-ene

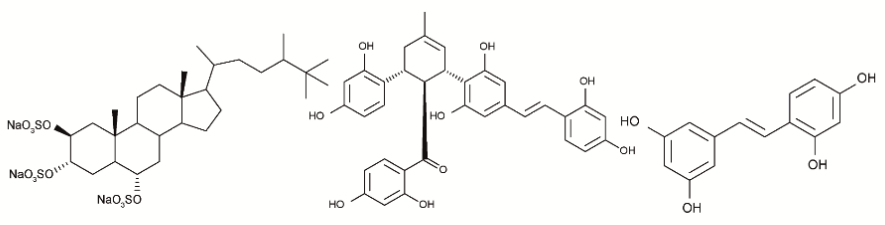

(26) Halistanol sulfate
(27) Kuwanon X
(28) Oxyresveratrol<smiles>CC(C)C(C)C(C(=O)Nc1ccccc1)c1ccccc1</smiles>

(29) N-benzoyl-(2'R,3'S)3'phenylisoserine

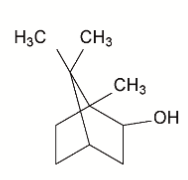

(31) Isoborneol

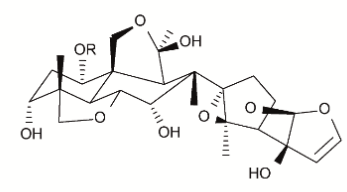

(32) 1-cinnamoyl-3,11dihydroxymeliacarpin

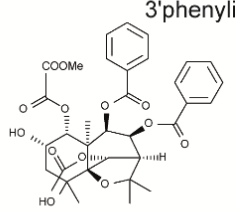

(33) Triptofordin C-2

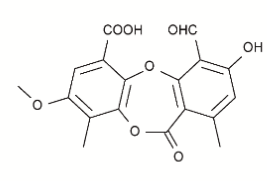

(34) Psoromic acid

Figure 2. Chemical structures of distinct compounds with antiviral activity against herpes simplex viruses, which were isolated from natural sources. Enumeration is consistent with Table 1, where the characteristics of the compounds are summarized in greater detail. 


\subsection{Inhibition of Viral Replication}

The major targets of substances inhibiting HSV replication are the viral enzymes DNA-polymerase and TK (Figure 3). Numerous compounds affecting HSV-TK or the viral DNA-polymerase could be isolated from plants and other natural sources. These include 28-deacetylsendanin (28-DAS), psoromic acid (PA), and samarangenin B (Sam B).

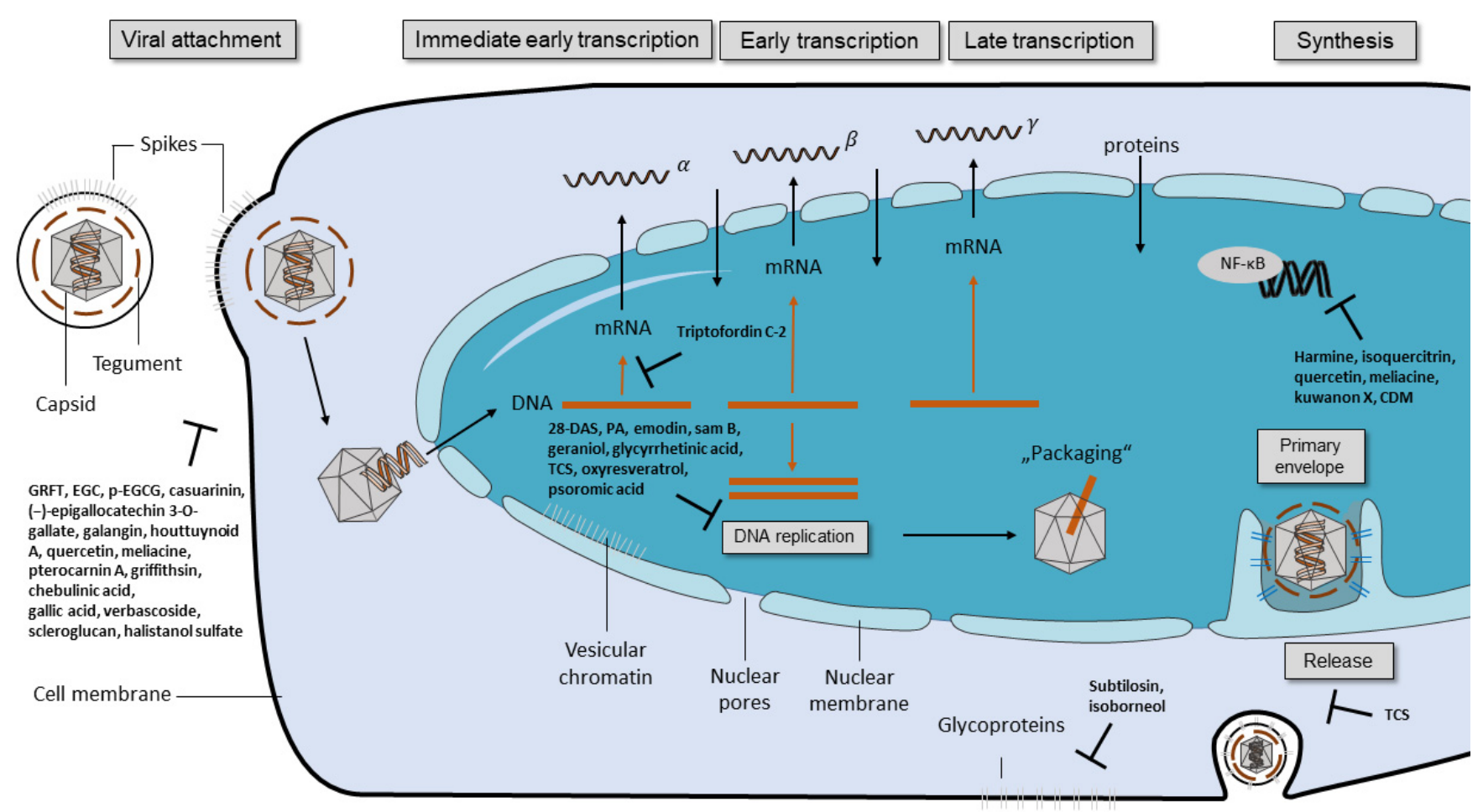

Figure 3. Replication cycle of herpes simplex viruses, including the targets of different natural antiviral compounds. During viral attachment, the viral glycoproteins $\mathrm{B}, \mathrm{D}$, and heterodimers of $\mathrm{gH} / \mathrm{gL}$ bind to the host cell receptors. The transcription phase is divided into immediate-early, early, and late transcription where HSV genes are transcribed as $\alpha$-, $\beta_{-}-$, and $\gamma$-genes, respectively. These mRNAs are translated into immediate-early, early, and late proteins. Following DNA replication and the synthesis of the viral capsid, the primary envelopment of the capsid takes place. Subsequently, the capsids are released from the nucleus. Then, virions are released after secondary envelopment. Antiviral compounds may directly interfere with the distinct steps of the viral replication cycle or influence the cellular factors that are important for viral replication. Substances disturbing the viral replication cycle are 28-DAS, PA, emodin, sam B, geraniol, glycyrrhetinic acid, TCS, oxyresveratrol, and psoromic acid. Compounds such as harmine, isoquercitrin, quercetin, meliacine, kuwanon $\mathrm{X}$, and CDM exhibit antiviral effects by addressing the primary essential cellular processes. The transcription factor NF- $k \mathrm{~B}$ is activated by HSV-1 and HSV-2, which favors the infection. GRFT = griffithsin, EGC = epigallocatechin, $p$-EGCG = palmitoyl-EGCG, 28-DAS = 28-deacetylsendanin, PA = psoromic acid, TCS = trichosanthin, CDM = 1-cinnamoyl-3,11-dihydroxymeliacarpin.

28-DAS is a terpene that was isolated from Melia azedarach, the Persian lilac tree. Extracts from leaves have been used as antiviral agents in traditional medicine. 28-DAS showed good antiviral activity toward HSV-1 cell culture experiments. The $50 \%$ inhibitory concentration $\left(\mathrm{IC}_{50}\right.$ ) of 28-DAS was determined with $1.46 \mu \mathrm{g} / \mathrm{mL}$. Subsequent analysis showed that there was a transient suppression of a $44 \mathrm{kDa}$ marked viral protein, which is important for viral replication. 28-DAS affects TK (p44) levels, suggesting that 28-DAS has primary, secondary, or both effects on TK [50].

PA is a $\beta$-orcinol depsidone that was isolated from Usnea fruticose lichens. It was uncovered to inactivate HSV-1 DNA-polymerase, which catalyzes the synthesis of DNA during HSV replication. Moreover, it was demonstrated that PA inhibited the DNApolymerase $\left(\mathrm{IC}_{50}=0.7 \mu \mathrm{M} ; \mathrm{Ki}=0.3 \mu \mathrm{M}\right)$ directly without any other prior activation or modification. In comparison, $\mathrm{ACV}\left(\mathrm{IC}_{50}=0.9 \mu \mathrm{M} ; \mathrm{Ki}=0.5 \mu \mathrm{M}\right)$ is initially phosphory- 
lated by the viral TK and modified by cellular enzymes before it can be processed by the HSV-DNA-polymerase. Based on an in silico study, PA was suggested to be a competitive inhibitor of HSV-2 DNA-polymerase. The antiviral activity was evaluated at an $\mathrm{IC}_{50}$ value of $1.9 \pm 0.42 \mu \mathrm{M}$ (SI: > 163.2) against HSV-1 and $2.7 \pm 0.43 \mu \mathrm{M}$ (SI: >114.8) against HSV-2 using a plaque reduction assay. Combination treatment of ACV and PA remarkably improved the anti-HSV efficacy at $\mathrm{EC}_{50}(50 \%$ effective concentration) values of $1.1 \pm 0.41 \mu \mathrm{M}$ for HSV-1 and $1.8 \pm 0.44 \mu \mathrm{M}$ for HSV-2. Cytotoxicity was determined with a $\mathrm{CC}_{50}(50 \%$ cytotoxic concentration) of $>310 \mu \mathrm{M}$ [56].

Sam B is a catechin purified from Limonium sinense. Sam B ( $\left.\mathrm{IC}_{50} \mathrm{HSV}-1: 11.4 \pm 0.9 \mu \mathrm{M}\right)$ showed higher antiviral activity than $\mathrm{ACV}\left(\mathrm{IC}_{50} \mathrm{HSV}-1\right.$ : $\left.55.4 \pm 5.3 \mu \mathrm{M}\right)$ in vitro, whereby cytotoxic effects could be excluded $\left(\mathrm{CC}_{50}:>100 \mu \mathrm{M}\right)$ [22]. In addition, the neutralization efficacy of Sam B did not differ between pre- and co-treatment conditions, indicating that Sam B does not interfere with the viral adsorption or penetration process. This finding supports the perception that Sam B expresses its activity at the level of viral replication. Furthermore, a decreased ICP0 and ICP4 gene expression was reported. These genes play important roles regulating $\beta$ and $\gamma$ gene expression, which is needed for HSV-1 replication (Figure 3). Sam B disturbs DNA-polymerase transcripts, synthesis, and consequently blocks the production of $\mathrm{gB}, \mathrm{gC}, \mathrm{gD}, \mathrm{gG}$, and ICP5. Moreover, Sam $\mathrm{B}$ reduced the level of $\mathrm{gB}$ mRNA significantly. Kuo et al. concluded that Sam B might be more potent in the treatment of reactivations than nucleoside analogues due to the high impact on immediate-early transcripts [21].

\subsection{Compounds Targeting Viral Glycoproteins}

The process by which HSV attaches to the cell surface and enters the cell is mediated by different glycoproteins on the surface of the virus. The attachment of the virion is initiated by an interaction between glycoprotein $C$ and heparan sulfate carbohydrates on the cell surfaces [63]. Glycoprotein D binds to cellular receptors such as Nectin-1 or HVEM (herpes virus entry mediator) and triggers the membrane fusion together with $\mathrm{gB}, \mathrm{gH}$, and $\mathrm{gL}$. Drugs targeting highly conserved epitopes on viral glycoproteins could be more resistant to mutations because particular sequences seem to be crucial for viral infectivity and fitness [64]. Hereafter, the compounds griffithsin (GRFT), (-)-epigallocatechin 3-O-gallate (EGCG), and isoborneol with their different possibilities of targeting viral glycoproteins are described.

GRFT is a peptide produced by the red alge Griffithsia. The results of the in vitro studies indicated an effect on the viral glycoproteins $\mathrm{B}, \mathrm{D}$, and heterodimers of $\mathrm{gH} / \mathrm{gL}$. Those are indispensable for virus entry and the HSV spread directly between adjacent cells (cell-to-cell spread). However, understanding the exact mechanisms of how GRFT interferes with the viral entry and transmission is not yet completely resolved [57]. GRFT was shown to protect target cells from HSV infection when the cells were pre-treated with the compound, indicating an inhibitory effect of GRFT on viral entry. Furthermore, GRFT was effective in inhibiting viral transmission in already infected cells (post-entry conditions) at an $\mathrm{EC}_{50}$ of $2.3 \mu \mathrm{g} / \mathrm{mL}$ [57]. Moreover, GRFT showed antiviral effectivity in vivo and protected mice from genital herpes disease after an application of $20 \mu \mathrm{L} 0.1 \%$ GRFT gel pre-infection [57]. GRFT neutralized the viral infection when the cells were pre-treated with concentrations of above $500 \mu \mathrm{g} / \mathrm{mL}$ [57]. The authors concluded that GRFT might affect the cell-to-cell transmission of the virus, thereby blocking viral infection [57].

Polyphenols isolated from tea plants such as Camellia sinensis from the family of Camelliaceae were shown to exceed antimicrobial and antiviral properties. One isolated component with anti-HSV-activity is EGCG. Isaacs et al. discussed that EGCG has the ability to interfere with the fusion process between the viral and cellular membranes by aggregating HSV glycoproteins B and D on the viral surface [25]. This finding was supported by the result that most virions pre-treated with EGCG were not infectious but appeared visually with an intact morphology [25]. 
Isoborneol from the Salvia fruticosa plant was shown to act dually as an antiviral agent against HSV-1. Firstly, the monoterpenoid alcohol inhibited HSV-1 protein glycosylation, resulting in an impairment of viral glycoprotein processing. Secondly, isoborneol directly inactivated HSV-1 at high concentrations, which was most probably by the interaction of its alcoholic moiety with lipids present on the viral envelope [51]. Infected Vero cells were treated with $0.06 \%$ isoborneol, and the viral loads decreased below the limit of analytical detection within $24 \mathrm{~h}$ [51].

\subsection{Compounds Suppressing NF- $\kappa B$ Activity}

NF- $\kappa B$ is a dimeric transcription factor, sequestered in the cytoplasm and, after its translocation into the nucleus, it mediates apoptotic, immune, or inflammatory responses. It was shown that NF- $\mathrm{BB}$ activation increases the efficiency of progeny HSV replication. In the early stages of HSV infection, gD-receptor interaction results in NF- $\mathrm{BB}$ nuclear translocation (early phase of infection) [65]. Furthermore, RNA-activated protein kinase also activates this process by the degradation of $I \kappa B$ in a later phase of infection [65]. Activated nuclear NF- $\mathrm{BB}$ participates in the synthesis of anti-apoptotic factors, which prevent a premature infection-induced cell death [66]. Based on these findings, compounds inhibiting NF- $\mathrm{B}$ activation or translocation may disturb viral replication through programmed cell death (Figure 3).

Kuwanon $\mathrm{X}$ is a stilbene derivative from the mulberry tree (Morus alba L.). In addition to inhibitory effects against viral penetration and IE gene expression, kuwanon $X$ therapy leads to NF- $\kappa B$ inactivation. Kuwanon $X$ showed to be more efficient in simultaneous $\left(\mathrm{IC}_{50} \mathrm{HSV}-1: 2.2 \mu \mathrm{g} / \mathrm{mL}\right)$ than in post-penetration treatment $\left(\mathrm{IC}_{50} \mathrm{HSV}-1: 3.0 \mu \mathrm{g} / \mathrm{mL}\right)$. This difference might be caused by the blocking of viral adsorption and penetration by kuwanon X. Additionally, kuwanon $X$ was shown to inhibit IE gene expression, which led to a reduced ICP4 and ICP27 protein synthesis. Those proteins are crucial for NF- $\mathrm{B}$ nuclear translocation. The missing translocation results in an earlier programmed cell death [46].

Melia azedarach, more commonly known as Persian lilac tree or Chinaberry, contains the tetranortriterpenoid 1-cinnamoyl-3,11-dihydroxymeliacarpin (CDM) targeting the NF$\kappa \mathrm{B}$ nuclear translocation. CDM showed inhibitory effects against HSV-1 with an $\mathrm{EC}_{50}$ value of $0.78 \mu \mathrm{M}$. Cytotoxicity could not be determined up to a concentration of $100 \mu \mathrm{M}$ on HCLE cells. The strong antiviral activity of CDM can be explained by multiple mechanisms. HSV glycoproteins B, C, and D are arrested into the Golgi complex by CDM causing an antiviral effect that is resilient against viral mutations. In addition, CDM blocks NF- $\mathrm{B}$ translocation in conjunctival cells infected with HSV-1. Although it was not possible to identify the specific target in this pathway, an accumulation of p65 in the cytoplasm could be observed after CDM therapy. It was assumed that p65 is related to the downregulation of either ubiquitination processes or IK kinase complex, which are both possible causes of a NF- $\mathrm{B}$ retention [52-54].

Quercetin and isoquercitrin are two major compounds of Houttuynia cordata, which were shown to suppress HSV replication by various mechanisms. Quercetin showed neutralizing activity at an $\mathrm{EC}_{50}$ value of $22.6 \pm 4.2 \mu \mathrm{g} / \mathrm{mL}$ against $\mathrm{HSV}-1$ and $86.7 \pm 7.4 \mu \mathrm{g} / \mathrm{mL}$ HSV-2 and isoquercitrin at among $0.42 \mu \mathrm{g} / \mathrm{mL}$ against HSV-1. Both compounds are characterized by a similar chemical structure. They effectively locked HSV-induced NF- $\mathrm{B}$ activation and NF- $\mathrm{KB}$ regulated IE genes transcription during the early phase of infection. Especially the ICP0 promoter was hindered by the downregulated NF- $\mathrm{KB}$ activation. ICP0 is meaningful for E and L gene expression. Quercetin and isoquercitrin blocked HSVrelated NF- $\mathrm{BB}$ activation in the anti-apoptotic pathway in the late phase of infection [27]. However, only quercetin blocked the viral cell-attachment and inhibited plaque formation in pre-treated cell culture $[27,67]$. 


\subsection{Compounds Affecting Viral Replication by Other Mechanisms}

Another promising substance with antiviral activity against HSV is glycyrrhizin (Figure 3). Mainly found in the root of the licorice plant Glycyrrhiza glabra, it targets multiple viruses such as HSV, hepatitis B and C, HIV, and coronaviruses. The anti-HSV1 activity was determined at an IC50 value of $225 \pm 24.1 \mu \mathrm{M}$. The anti-inflammatory and immunoregulative properties of glycyrrhizin have been previously reported [34]. Glycyrrhizin inhibits HSV-1 entry into the cells via targeting adhesion molecules on the surface of the target cells [33,34].

Trichosanthin (TCS) is a protein derived from the roots of Trichosanthes kirilowii and known for its antiviral activity against HSV-1 and other viruses such as HIV-1. TCS neutralized HSV-1 at an $\mathrm{EC}_{50}$ of $38.4 \mu \mathrm{g} / \mathrm{mL}$ (subtoxic concentration). The drug synergy of combinatory treatment with TCS and ACV was observed, as the combination of TCS and small amounts of ACV showed a hundredfold higher neutralizing efficacy in vitro than TCS treatment alone [60-62]. The authors concluded that TCS uses a different mechanism of interfering with viral replication than ACV. Time-dependent cell culture experiments revealed an inhibitory effect of TCS against HSV-1 release, which leads to the conclusion that the virion maturation (protein synthesis and/or DNA replication) was inhibited by TCS [60-62]. Furthermore, an increased number of apoptotic cells in TCS treated and infected cultures was observed. HSV infections generally activate p38 Mitogen-Activated Protein Kinase (MAPK) and pro-survival protein Bcl-2. The latter blocks the mitochondrial release of cytochrome $\mathrm{c}$, allowing the virus to replicate more efficiently. TCS was shown to decrease MAPK and Bcl-2 activity, most probably by inhibiting a step during viral replication [60-62]. However, uncovering the exact mechanism of how TCS interferes with the replication of HSV needs further investigation.

\subsection{Efficacy of Natural Compounds In Vivo}

Numerous natural compounds were shown to exhibit antiviral activity against HSV-1 and HSV-2 in vitro. To investigate whether these results can be extrapolated to living organisms, in vivo studies are necessary. However, only a few natural compounds that showed antiviral activity in cell culture experiments (Table 1) were further evaluated in animal studies. These compounds are discussed in the following section and summarized in Table 2.

The natural compound emodin contained in the plant Rheum tanguticum belongs to the anthraquinone family. Emodin reduced the replication of HSV-1 and HSV-2 on human laryngeal carcinoma (HEp-2) cells in vitro [17]. The antiviral efficacy of emodin was further investigated in mice. BALB/c mice were intracerebrally infected with a lethal dose of HSV-1 or HSV-2. Subsequently, the infected mice were orally treated with different amounts of emodin for seven days in $8 \mathrm{~h}$ intervals. The mice were observed for 40 days. Emodin protected the mice from a lethal outcome of infection in a dose-dependent manner. The survival was significantly higher in mice treated with emodin at $6.7 \mathrm{~g} / \mathrm{kg} /$ day comparted to untreated control, in which all the mice died [17]. Notably, the treatment with emodin was even more effective than $0.1 \mathrm{mg} / \mathrm{kg} /$ day ACV orally in terms of increasing the survival rate and mean time to death of the infected mice [17].

Another compound that showed antiviral activity against HSV-1 in vitro and in vivo is the flavonoid baicalein, which is isolated from the roots of Scutellaria baicalensis [24]. Oral administration of baicalein at a dose of $200 \mathrm{mg} / \mathrm{kg} /$ day for seven days significantly increased the survival rate of mice that were intranasally infected with a lethal dose of HSV-1 [24]. However, the survival rate was higher in the ACV group (50 mg/kg/day) than in the baicalein group $(200 \mathrm{mg} / \mathrm{kg} /$ day). The natural compound oxyresveratrol isolated from Artocarpus lakoocha exhibited an antiviral effect against HSV-1 and HSV-2 in vitro by inhibiting the early and late viral genes $[47,48]$. However, the administration of the compound only slightly increased the survival rate of mice with a cutaneous HSV-1 infection, and there was no significant difference compared to an untreated control [47]. 
Table 2. In vivo studies of anti-HSV chemical substances. P.O. = Per Os.

\begin{tabular}{|c|c|c|c|c|c|c|c|c|c|}
\hline Group & Compound & Plant/Other & Animal & Virus & $\begin{array}{l}\text { Way of } \\
\text { Infection }\end{array}$ & Treatment; Dose & $\begin{array}{l}\text { Survival under } \\
\text { Treatment }\end{array}$ & $\begin{array}{l}\text { Compared to } \\
\text { Control/ACV }\end{array}$ & Refs. \\
\hline Anthraquinone & e Emodin & $\begin{array}{l}\text { Rheum } \\
\text { tanguticum }\end{array}$ & $\begin{array}{l}\mathrm{BALB} / \mathrm{c} \\
\text { mice }\end{array}$ & $\begin{array}{c}\text { HSV-1F; } \\
\text { HSV-2 (333) }\end{array}$ & Intracerebral & $\begin{array}{c}\text { P.O.; } \\
6.7 \mathrm{~g} / \mathrm{kg} / \text { day }\end{array}$ & $\begin{array}{l}\text { HSV-1: } 61.5 \% \\
\text { HSV-2: } \approx 70 \%\end{array}$ & $\begin{array}{l}\text { HSV-1: Untreated } \\
\text { control: } 0 \% / \mathrm{ACV} \text { : } \\
\approx 20 \%(p<0.01) \\
\text { HSV-2: Untreated } \\
\text { control: } 0 \% / \mathrm{ACV} \text { : } \\
\approx 30 \%(p<0.01)\end{array}$ & [17] \\
\hline Flavinoid & Baicalein & $\begin{array}{l}\text { Scutellaria } \\
\text { baicalensis }\end{array}$ & $\begin{array}{l}\mathrm{BALB} / \mathrm{c} \\
\text { mice }\end{array}$ & HSV-1 F & Intranasal & $\begin{array}{c}\text { P.O.; } \\
200 \mathrm{mg} / \mathrm{kg} / \text { day }\end{array}$ & $75 \%$ & $\begin{array}{l}\text { Untreated control: } \\
33.3 \% \\
\begin{array}{c}(p<0.05) / \mathrm{ACV}: \\
\approx 90 \%\end{array}\end{array}$ & [24] \\
\hline Harmaline & $\begin{array}{l}\text { 7-methoxy-1- } \\
\text { methyl-4,9- } \\
\text { dihydro-3H- } \\
\text { pyrido[3,4- } \\
\text { b]indole }\end{array}$ & $\begin{array}{c}\text { Ophiorrhiza } \\
\text { nicobarica } \\
\text { Balkr }\end{array}$ & $\begin{array}{c}\text { BALB } / \mathrm{c} \\
\text { mice } \\
\text { (female and } \\
\text { male) }\end{array}$ & HSV-2 G & Genital & $\begin{array}{l}\text { P.O.; } 0.25 \text { and } \\
0.5 \mathrm{mg} / \mathrm{kg} 6 \mathrm{~h} \\
\text { after infection }\end{array}$ & $\begin{array}{c}0.25 \mathrm{mg} / \mathrm{kg}: \\
45 \% \\
0.5 \mathrm{mg} / \mathrm{kg}: \\
70 \%\end{array}$ & $\begin{array}{c}\text { Untreated control: } \\
5 \%(p<0.05) / \mathrm{ACV} \text { : } \\
80 \%\end{array}$ & {$[30]$} \\
\hline Peptide & $\begin{array}{l}\text { Griffithsin } \\
\text { (GRFT) }\end{array}$ & Griffithsia & $\begin{array}{l}\text { BALB/c } \\
\text { mice } \\
\text { (female) }\end{array}$ & HSV-2 & Intravaginal & $\begin{array}{c}\text { Intravaginal } \\
\text { topically; } 20 \mu \mathrm{L} \\
0.1 \% \text { GRFT gel } \\
\text { pre-infection }\end{array}$ & $\approx 80 \%$ & $\begin{array}{l}\text { Untreated control: } \\
\approx 20 \%(p<0.05)\end{array}$ & [57] \\
\hline Phenolics & Curcumin & $\begin{array}{c}\text { The curry } \\
\text { spice turmeric }\end{array}$ & $\begin{array}{l}\text { BALB/c } \\
\text { mice } \\
\text { (female) }\end{array}$ & HSV-2 (333) & Intravaginal & $\begin{array}{c}\text { Intravaginal } \\
\text { topically; } 100 \mu \mathrm{g} \\
6 \mathrm{~h} \text { pre-infection }\end{array}$ & $0 \%$ & $0 \%$ & [68] \\
\hline Polysaccharids & MI-S & $\begin{array}{l}\text { Agaricus } \\
\text { brasiliensis }\end{array}$ & $\begin{array}{l}\mathrm{BALB} / \mathrm{c} \\
\text { mice } \\
\text { (female) }\end{array}$ & HSV-2 (333) & Intravaginal & $\begin{array}{c}\text { Intravaginal } \\
\text { topically; } \\
20 \mathrm{mg} / \mathrm{mL} 20 \mathrm{~min} \\
\text { pre-infection }\end{array}$ & $60 \%$ & $\begin{array}{l}\text { Untreated control: } \\
0 \%(p<0.0001)\end{array}$ & [69] \\
\hline $\begin{array}{l}\text { Stilbenoids } \\
\quad \text { and } \mathrm{O} \\
\text { 2-arylbenzofura }\end{array}$ & $\begin{array}{l}\text { Oxyresveratrol } \\
\text { ans }\end{array}$ & $\begin{array}{l}\text { Artocarpus } \\
\text { lakoocha }\end{array}$ & $\begin{array}{l}\mathrm{BALB} / \mathrm{c} \\
\text { mice } \\
\text { (female) }\end{array}$ & $\begin{array}{l}\text { HSV-1 } \\
(7401 \mathrm{H})\end{array}$ & Cutaneous & $\begin{array}{l}\text { P.O.; } 500 \mathrm{mg} / \mathrm{kg} \\
8 \mathrm{~h} \text { pre-infection } \\
\text { and } 3 \mathrm{x} \text { daily for } \\
7 \text { days after } \\
\text { infection }\end{array}$ & $25 \%$ & $\begin{array}{c}\text { Untreated control: } \\
0 \%(n . s .) / \mathrm{ACV}: \\
100 \%\end{array}$ & [47] \\
\hline \multirow[t]{2}{*}{ Terpene } & \multirow{2}{*}{$\begin{array}{l}\text { Meliacine } \\
(\mathrm{CDM})\end{array}$} & \multirow{2}{*}{$\begin{array}{c}\text { Melia } \\
\text { azedarach } \mathrm{L} .\end{array}$} & $\begin{array}{l}\mathrm{BALB} / \mathrm{c} \\
\text { mice } \\
\text { (female) }\end{array}$ & $\begin{array}{l}\text { HSV-2 MS } \\
\text { and G }\end{array}$ & Intravaginal & $\begin{array}{l}\text { Intravaginal } \\
\text { topically; } 1 \mathrm{mg} 2 \mathrm{x} \\
\text { daily for } 5 \text { days }\end{array}$ & $\begin{array}{l}\text { HSV-2 MS: } 20 \% \\
\text { HSV-2 G: } 86 \%\end{array}$ & $\begin{array}{l}\text { Untreated control: } \\
\text { HSV-2 MS: } 0 \% \text {; } \\
\text { HSV-2 G: } 42 \%\end{array}$ & {$[70]$} \\
\hline & & & $\begin{array}{c}\text { BALB } / \mathrm{c} \\
\text { mice } \\
\text { (female and } \\
\text { male) }\end{array}$ & HSV-1 (KOS) & Corneal & $\begin{array}{l}\text { Corneal topically; } \\
\text { 3x daily } 1 \text { day } \\
\text { pre-infection and } \\
\text { for } 3 \text { days after } \\
\text { infection }\end{array}$ & $\begin{array}{l}\text { Development } \\
\text { of keratitis: } 5 \%\end{array}$ & $\begin{array}{l}\text { Untreated control: } \\
90 \%(p<0.001)\end{array}$ & {$[71]$} \\
\hline
\end{tabular}

Some compounds were also tested for their antiviral effectivity in treating genital HSV-2 infections, including curcumin, GRFT, meliacine, 7-methoxy-1-methyl-4,9-dihydro$3 \mathrm{H}$-pyrido [3,4-b]indole (HM), and MI-S [30,57,68-71]. Intravaginal administration with $100 \mu \mathrm{g}$ curcumin six hours before vaginal infection with HSV-2 significantly increased the survival time of mice compared to the untreated control [68]. However, prophylactic treatment with curcumin could only delay the lethal outcome of infection, and all mice died after 20 days post infection. Further in vivo studies with other natural compounds including the peptide GRFT isolated from the alga Griffithsia, the harmaline HM from the herb Ophiorrhiza nicobarica Balkr, as well as the polysaccharide MI-S isolated from the fungus Agaricus brasiliensis showed that these compounds significantly increased the survival rate of mice intravaginally infected with HSV-2 [30,57,69]. In the experiments, MI-S and GRFT were vaginally administered before infection, and $\mathrm{HM}$ was orally administered after infection with HSV-2. However, depending on the dose of HM administered, the survival rate of mice treated with ACV was at least 10\% higher compared to HM treatment [30]. Furthermore, the terpene meliacine, from which CDM can be obtained, was shown to protect mice from developing severe genital HSV-2 infection. In this study, $50 \mathrm{mg}$ of meliacine was vaginally administered as cream twice a day for five consecutive days [70]. In a further study, topical administration of meliciacie was also effective in preventing mice with a corneal HSV-1 infection from developing severe keratitis. Only $5 \%$ of treated mice showed signs of keratitis. The untreated group reached levels from 85 to $90 \%$ [71]. 


\section{Summary and Additional Comments}

The current standard therapy for HSV primary infection and reactivation includes $\mathrm{ACV}$ and valacyclovir. However, the emergence of drug resistances limits the available treatment options [5]. Therefore, there is a clear need for the development of new effective antiviral drugs. Plants traditionally used for medical purposes are a promising source of new antiviral compounds.

In the present review, we summarized compounds isolated from plants, bacteria, and fungi with different mechanisms inhibiting HSV, including the inhibition of viral attachment, penetration, and replication. The compounds belong to different groups such as catechins, flavonoids, phenolic acids, polysaccharides, terpenes, and peptides. With six compounds, flavonoids represent the largest group.

Some of the tested compounds showed a similar or even better antiviral activity against HSV-1 than ACV in vitro, including the anthraquinone emodin, the catechin epigallocatechin (EGC), the harmaline HM, and the $\beta$-orcinol depsidone PA as well as other promising compounds (Table 1 and Figure 1) [17,18,31,35,44,56]. Interestingly, when these compounds were supplemented with geraniol, they had a similar or better antiviral activity against HSV-2 [17,18,30,32,36,56]. These candidates might be good for further evaluation in the search for alternative treatments of ACV-resistant viruses. Additional studies are needed to investigate whether these compounds maintain their antiviral activity against HSV-1 and HSV-2 clinical isolates that are resistant to ACV. To date, only a few studies have included ACV-resistant strains in their experiments $[4,47,69]$. In the study of Luo et al. (2020), the antiviral effect of baicalein against an ACV-resistant HSV-1 strain (HSV-1 Blue) was comparable in its effect against the HSV-1 F strain without resistance [24]. As anticipated, $\mathrm{ACV}$ exhibited only a weak antiviral activity against the ACV-resistant virus. However, ACV showed a stronger inhibition against the HSV-1 F strain than baicalein. In a further in vitro study, the antiviral effect of MI-S was observed against HSV-1 KOS, an ACV-resistant HSV-1 strain (HSV-1 29R), and HSV-2 333 [69]. MI-S was similarly effective against HSV-1 KOS and HSV-1 29R when the compound was administered during or after infection. ACV showed no inhibitory activity against HSV-1 KOS when applied simultaneously with the virus, but it was more effective than MI-S under post-infection treatment conditions.

Only a few of those compounds were evaluated for their efficacy against HSV infections in in vivo studies. Of these compounds, emodin exhibited promising results, as it strongly increased the survival rate of mice infected with HSV-1 and HSV-2 [17]. The compound was even more effective than $\mathrm{ACV}$ in increasing the survival rate and mean time to death. Furthermore, HM significantly increased the survival rate of mice infected with HSV-2 [30]. Although standard therapy with ACV was more effective, the increase of survival through the compound was still striking. The results of these studies indicate that emodin and HM are promising candidates for future clinical trials. Clearly, there is a need for more elaborate in vivo studies as well as clinical trials that compare the compounds to the standard therapy of HSV.

\section{Conclusions}

To date, numerous herbal medicines and their main ingredients were investigated for their antiviral efficacy against HSV-1 and HSV-2 in cell culture and animal models. For instance, the anthraquinone emodin derived from the plant Rheum tanguticum as well as the harmaline HM isolated from the herb Ophiorrhiza nicobarica Balkr exhibited a strong antiviral effect against HSV in vitro and in vivo, which were comparable to or even better than ACV. Clinical studies are needed to determine the efficacy of these compounds in humans. Furthermore, natural compounds might be an effective substitute for drugs such as ACV in the treatment of ACV-resistant HSV infections. Taken together, herbal medicines represent a promising source to isolate novel compounds with antiviral activity against HSV-1 and HSV-2. Numerous compounds could be isolated and pre-clinically 
characterized thus far. Further clinical evaluation of the agents that are most promising in animal trials may lead to the development of novel therapy options in humans.

Author Contributions: Conceptualization, L.v.d.S., M.B., O.W. and A.K.; writing-original draft preparation, L.v.d.S., M.B., Y.S., C.S.H., O.W. and A.K.; writing-review and editing, C.S.H.; visualization, L.v.d.S. and M.B.; supervision, A.K.; funding acquisition, L.v.d.S., O.W. and A.K. All authors have read and agreed to the published version of the manuscript.

Funding: This study was supported by the Stiftung Universitätsmedizin Essen (awarded to A. Krawczyk), the Else-Kröner Promotionskolleg ELAN (awarded to L. van de Sand), and the Rudolf Ackermann Foundation (awarded to O. Witzke).

Institutional Review Board Statement: Not applicable.

Informed Consent Statement: Not applicable.

Acknowledgments: The authors thank Delia Cosgrove for proofreading of the manuscript.

Conflicts of Interest: The authors declare no conflict of interest.

\section{References}

1. Pebody, R.; Andrews, N.; Brown, D.; Gopal, R.; Melker, H.; François, G.; Gatcheva, N.; Hellenbrand, W.; Jokinen, S.; Klavs, I.; et al. The seroepidemiology of herpes simplex virus type 1 and 2 in Europe. Sex. Transm. Infect. 2004, 80, 185-191. [CrossRef] [PubMed]

2. Berrington, W.R.; Jerome, K.R.; Cook, L.; Wald, A.; Corey, L.; Casper, C. Clinical correlates of herpes simplex virus viremia among hospitalized adults. Clin. Infect. Dis. Off. Publ. Infect. Dis. Soc. Am. 2009, 49, 1295-1301. [CrossRef] [PubMed]

3. Kimberlin, D.W.; Lin, C.Y.; Jacobs, R.F.; Powell, D.A.; Corey, L.; Gruber, W.C.; Rathore, M.; Bradley, J.S.; Diaz, P.S.; Kumar, M.; et al. Safety and efficacy of high-dose intravenous acyclovir in the management of neonatal herpes simplex virus infections. Pediatrics 2001, 108, 230-238. [CrossRef]

4. Akinyi, B.; Odhiambo, C.; Otieno, F.; Inzaule, S.; Oswago, S.; Kerubo, E.; Ndivo, R.; Zeh, C. Prevalence, incidence and correlates of HSV-2 infection in an HIV incidence adolescent and adult cohort study in western Kenya. PLoS ONE 2017, 12, e0178907. [CrossRef] [PubMed]

5. Jiang, Y.-C.; Feng, H.; Lin, Y.-C.; Guo, X.-R. New strategies against drug resistance to herpes simplex virus. Int. J. Oral Sci. 2016, 8, 1-6. [CrossRef]

6. $\quad$ Baeten, J.M.; Strick, L.B.; Lucchetti, A.; Whittington, W.L.; Sanchez, J.; Coombs, R.W.; Magaret, A.; Wald, A.; Corey, L.; Celum, C. Herpes simplex virus (HSV)-suppressive therapy decreases plasma and genital HIV-1 levels in HSV-2/HIV-1 coinfected women: A randomized, placebo-controlled, cross-over trial. J. Infect. Dis. 2008, 198, 1804-1808. [CrossRef]

7. Delany, S.; Mlaba, N.; Clayton, T.; Akpomiemie, G.; Capovilla, A.; Legoff, J.; Belec, L.; Stevens, W.; Rees, H.; Mayaud, P. Impact of aciclovir on genital and plasma HIV-1 RNA in HSV-2/HIV-1 co-infected women: A randomized placebo-controlled trial in South Africa. AIDS 2009, 23, 461-469. [CrossRef]

8. Nagot, N.; Ouédraogo, A.; Foulongne, V.; Konaté, I.; Weiss, H.A.; Vergne, L.; Defer, M.C.; Djagbaré, D.; Sanon, A.; Andonaba, J.B.; et al. Reduction of HIV-1 RNA levels with therapy to suppress herpes simplex virus. N. Engl. J. Med. 2007, 356, 790-799. [CrossRef]

9. McMahon, M.A.; Siliciano, J.D.; Lai, J.; Liu, J.O.; Stivers, J.T.; Siliciano, R.F.; Kohli, R.M. The antiherpetic drug acyclovir inhibits HIV replication and selects the V75I reverse transcriptase multidrug resistance mutation. J. Biol. Chem. 2008, 283, 31289-31293. [CrossRef]

10. Matamoros, T.; Kim, B.; Menéndez-Arias, L. Mechanistic insights into the role of Val75 of HIV-1 reverse transcriptase in misinsertion and mispair extension fidelity of DNA synthesis. J. Mol. Biol. 2008, 375, 1234-1248. [CrossRef]

11. Farooq, A.V.; Shukla, D. Herpes simplex epithelial and stromal keratitis: An epidemiologic update. Surv. Ophthalmol. 2012, 57, 448-462. [CrossRef] [PubMed]

12. Stránská, R.; Schuurman, R.; Nienhuis, E.; Goedegebuure, I.W.; Polman, M.; Weel, J.F.; Wertheim-Van Dillen, P.M.; Berkhout, R.J.; van Loon, A.M. Survey of acyclovir-resistant herpes simplex virus in the Netherlands: Prevalence and characterization. J. Clin. Virol. 2005, 32, 7-18. [CrossRef] [PubMed]

13. Sauerbrei, A.; Bohn, K.; Heim, A.; Hofmann, J.; Weissbrich, B.; Schnitzler, P.; Hoffmann, D.; Zell, R.; Jahn, G.; Wutzler, P.H.; et al. Novel resistance-associated mutations of thymidine kinase and DNA polymerase genes of herpes simplex virus type 1 and type 2. Antivir. Ther. 2011, 16, 1297-1308. [CrossRef] [PubMed]

14. Blot, N.; Schneider, P.; Young, P.; Janvresse, C.; Dehesdin, D.; Tron, P.; Vannier, J.P. Treatment of an acyclovir and foscarnet-resistant herpes simplex virus infection with cidofovir in a child after an unrelated bone marrow transplant. Bone Marrow Transpl. 2000, 26, 903-905. [CrossRef] [PubMed]

15. Chen, D.; Su, A.; Fu, Y.; Wang, X.; Lv, X.; Xu, W.; Xu, S.; Wang, H.; Wu, Z. Harmine blocks herpes simplex virus infection through downregulating cellular NF-kB and MAPK pathways induced by oxidative stress. Antivir. Res. 2015, 123, 27-38. [CrossRef] 
16. Hutterer, C.; Milbradt, J.; Hamilton, S.; Zaja, M.; Leban, J.; Henry, C.; Vitt, D.; Steingruber, M.; Sonntag, E.; Zeitträger, I.; et al. Inhibitors of dual-specificity tyrosine phosphorylation-regulated kinases (DYRK) exert a strong anti-herpesviral activity. Antivir. Res. 2017, 143, 113-121. [CrossRef]

17. Xiong, H.R.; Luo, J.; Hou, W.; Xiao, H.; Yang, Z.Q. The effect of emodin, an anthraquinone derivative extracted from the roots of Rheum tanguticum, against herpes simplex virus in vitro and in vivo. J. Ethnopharmacol. 2011, 133, 718-723. [CrossRef]

18. Lyu, S.Y.; Rhim, J.Y.; Park, W.B. Antiherpetic activities of flavonoids against herpes simplex virus type 1 (HSV-1) and type 2 (HSV-2) in vitro. Arch. Pharm. Res. 2005, 28, 1293-1301. [CrossRef]

19. Isaacs, C.E.; Wen, G.Y.; Xu, W.; Jia, J.H.; Rohan, L.; Corbo, C.; Di Maggio, V.; Jenkins, E.C., Jr.; Hillier, S. Epigallocatechin gallate inactivates clinical isolates of herpes simplex virus. Antimicrob. Agents Chemother. 2008, 52, 962-970. [CrossRef] [PubMed]

20. de Oliveira, A.; Adams, S.D.; Lee, L.H.; Murray, S.R.; Hsu, S.D.; Hammond, J.R.; Dickinson, D.; Chen, P.; Chu, T.C. Inhibition of herpes simplex virus type 1 with the modified green tea polyphenol palmitoyl-epigallocatechin gallate. Food Chem. Toxicol. 2013, 52, 207-215. [CrossRef] [PubMed]

21. Kuo, Y.C.; Lin, L.C.; Tsai, W.J.; Chou, C.J.; Kung, S.H.; Ho, Y.H. Samarangenin B from Limonium sinense suppresses herpes simplex virus type 1 replication in Vero cells by regulation of viral macromolecular synthesis. Antimicrob. Agents Chemother. 2002, 46, 2854-2864. [CrossRef]

22. Lin, L.C.; Kuo, Y.C.; Chou, C.J. Anti-herpes simplex virus type-1 flavonoids and a new flavanone from the root of Limonium sinense. Planta Med. 2000, 66, 333-336. [CrossRef] [PubMed]

23. Cheng, H.Y.; Lin, C.C.; Lin, T.C. Antiherpes simplex virus type 2 activity of casuarinin from the bark of Terminalia arjuna Linn. Antivir. Res. 2002, 55, 447-455. [CrossRef]

24. Luo, Z.; Kuang, X.P.; Zhou, Q.Q.; Yan, C.Y.; Li, W.; Gong, H.B.; Kurihara, H.; Li, W.X.; Li, Y.F.; He, R.R. Inhibitory effects of baicalein against herpes simplex virus type 1. Acta Pharm. Sin. B 2020, 10, 2323-2338. [CrossRef]

25. Isaacs, C.E.; Xu, W.; Merz, G.; Hillier, S.; Rohan, L.; Wen, G.Y. Digallate dimers of (-)-epigallocatechin gallate inactivate herpes simplex virus. Antimicrob. Agents Chemother. 2011, 55, 5646-5653. [CrossRef]

26. Li, T.; Liu, L.; Wu, H.; Chen, S.; Zhu, Q.; Gao, H.; Yu, X.; Wang, Y.; Su, W.; Yao, X.; et al. Anti-herpes simplex virus type 1 activity of Houttuynoid A, a flavonoid from Houttuynia cordata Thunb. Antivir. Res. 2017, 144, 273-280. [CrossRef]

27. Hung, P.Y.; Ho, B.C.; Lee, S.Y.; Chang, S.Y.; Kao, C.L.; Lee, S.S.; Lee, C.N. Houttuynia cordata targets the beginning stage of herpes simplex virus infection. PLoS ONE 2015, 10, e0115475. [CrossRef]

28. Chiang, L.C.; Chiang, W.; Liu, M.C.; Lin, C.C. In vitro antiviral activities of Caesalpinia pulcherrima and its related flavonoids. J. Antimicrob. Chemother. 2003, 52, 194-198. [CrossRef]

29. Cheng, H.Y.; Lin, T.C.; Yang, C.M.; Wang, K.C.; Lin, C.C. Mechanism of action of the suppression of herpes simplex virus type 2 replication by pterocarnin A. Microbes Infect. 2004, 6, 738-744. [CrossRef] [PubMed]

30. Bag, P.; Ojha, D.; Mukherjee, H.; Halder, U.C.; Mondal, S.; Chandra, N.S.; Nandi, S.; Sharon, A.; Sarkar, M.C.; Chakrabarti, S.; et al. An Indole Alkaloid from a Tribal Folklore Inhibits Immediate Early Event in HSV-2 Infected Cells with Therapeutic Efficacy in Vaginally Infected Mice. PLoS ONE 2013, 8, e77937. [CrossRef]

31. Bag, P.; Ojha, D.; Mukherjee, H.; Halder, U.C.; Mondal, S.; Biswas, A.; Sharon, A.; Van Kaer, L.; Chakrabarty, S.; Das, G.; et al. A dihydro-pyrido-indole potently inhibits HSV-1 infection by interfering the viral immediate early transcriptional events. Antivir. Res. 2014, 105, 126-134. [CrossRef]

32. Hassan, S.T.S.; Berchová-Bímová, K.; Šudomová, M.; Malaník, M.; Šmejkal, K.; Rengasamy, K.R.R. In Vitro Study of MultiTherapeutic Properties of Thymus bovei Benth. Essential Oil and Its Main Component for Promoting Their Use in Clinical Practice. J. Clin. Med. 2018, 7, 283. [CrossRef]

33. Ikeda, T.; Yokomizo, K.; Okawa, M.; Tsuchihashi, R.; Kinjo, J.; Nohara, T.; Uyeda, M. Anti-herpes virus type 1 activity of oleanane-type triterpenoids. Biol. Pharm. Bull. 2005, 28, 1779-1781. [CrossRef]

34. Huang, W.; Chen, X.; Li, Q.; Li, P.; Zhao, G.; Xu, M.; Xie, P. Inhibition of intercellular adhesion in herpex simplex virus infection by glycyrrhizin. Cell Biochem. Biophys. 2012, 62, 137-140. [CrossRef] [PubMed]

35. Lin, L.T.; Chen, T.Y.; Chung, C.Y.; Noyce, R.S.; Grindley, T.B.; McCormick, C.; Lin, T.C.; Wang, G.H.; Lin, C.C.; Richardson, C.D Hydrolyzable tannins (chebulagic acid and punicalagin) target viral glycoprotein-glycosaminoglycan interactions to inhibit herpes simplex virus 1 entry and cell-to-cell spread. J. Virol. 2011, 85, 4386-4398. [CrossRef]

36. Kesharwani, A.; Polachira, S.K.; Nair, R.; Agarwal, A.; Mishra, N.N.; Gupta, S.K. Anti-HSV-2 activity of Terminalia chebula Retz extract and its constituents, chebulagic and chebulinic acids. BMC Complement. Altern. Med. 2017, 17, 110. [CrossRef]

37. Kratz, J.M.; Andrighetti-Fröhner, C.R.; Kolling, D.J.; Leal, P.C.; Cirne-Santos, C.C.; Yunes, R.A.; Nunes, R.J.; Trybala, E.; Bergström, T.; Frugulhetti, I.C.; et al. Anti-HSV-1 and anti-HIV-1 activity of gallic acid and pentyl gallate. Mem. Inst. Oswaldo Cruz. 2008, 103, 437-442. [CrossRef]

38. Kratz, J.M.; Andrighetti-Fröhner, C.R.; Leal, P.C.; Nunes, R.J.; Yunes, R.A.; Trybala, E.; Bergström, T.; Barardi, C.R.; Simões, C.M. Evaluation of anti-HSV-2 activity of gallic acid and pentyl gallate. Biol. Pharm. Bull. 2008, 31, 903-907. [CrossRef]

39. El-Toumy, S.; Salib, J.; El-Kashak, W.; Marty, C.; Bedoux, G.; Bourgougnon, N. Antiviral effect of polyphenol rich plant extracts on herpes simplex virus type 1. Food Sci. Hum. Wellness 2018, 7, 91-101. [CrossRef]

40. Kutluay, S.B.; Doroghazi, J.; Roemer, M.E.; Triezenberg, S.J. Curcumin inhibits herpes simplex virus immediate-early gene expression by a mechanism independent of p300/CBP histone acetyltransferase activity. Virology 2008, 373, 239-247. [CrossRef] 
41. Martins, F.O.; Esteves, P.F.; Mendes, G.S.; Barbi, N.S.; Menezes, F.S.; Romanos, M.T. Verbascoside isolated from Lepechinia speciosa has inhibitory activity against HSV-1 and HSV-2 in vitro. Nat. Prod. Commun. 2009, 4, 1693-1696. [CrossRef] [PubMed]

42. de Sousa Cardozo, F.T.G.; Camelini, C.M.; Mascarello, A.; José Rossi, M.; José Nunes, R.; Monte Barardi, C.R.; de Mendonça, M.M.; Simões, C.M.O. Antiherpetic activity of a sulfated polysaccharide from Agaricus brasiliensis mycelia. Antivir. Res. 2011, 92, 108-114. [CrossRef]

43. Marchetti, M.; Pisani, S.; Pietropaolo, V.; Seganti, L.; Nicoletti, R.; Degener, A.; Orsi, N. Antiviral effect of a polysaccharide from Sclerotium glucanicum towards herpes simplex virus type 1 infection. Planta Med. 1996, 62, 303-307. [CrossRef] [PubMed]

44. Álvarez, Á.; Habtemariam, S.L.; Abdel Moneim, A.E.; Melón, S.; Dalton, K.P.; Parra, F. A spiroketal-enol ether derivative from Tanacetum vulgare selectively inhibits HSV-1 and HSV-2 glycoprotein accumulation in Vero cells. Antivir. Res. 2015, 119, 8-18. [CrossRef]

45. da Rosa Guimarães, T.; Quiroz, C.G.; Borges, C.R.; de Oliveira, S.Q.; de Almeida, M.T.; Bianco, É.M.; Moritz, M.I.; Carraro, J.L.; Palermo, J.A.; Cabrera, G.; et al. Anti HSV-1 activity of halistanol sulfate and halistanol sulfate C isolated from Brazilian marine sponge Petromica citrina (Demospongiae). Mar. Drugs 2013, 11, 4176-4192. [CrossRef]

46. Ma, F.; Shen, W.; Zhang, X.; Li, M.; Wang, Y.; Zou, Y.; Li, Y.; Wang, H. Anti-HSV Activity of Kuwanon X from Mulberry Leaves with Genes Expression Inhibitory and HSV-1 Induced NF-kB Deactivated Properties. Biol. Pharm. Bull. 2016, 39, 1667-1674. [CrossRef]

47. Chuanasa, T.; Phromjai, J.; Lipipun, V.; Likhitwitayawuid, K.; Suzuki, M.; Pramyothin, P.; Hattori, M.; Shiraki, K. Anti-herpes simplex virus (HSV-1) activity of oxyresveratrol derived from Thai medicinal plant: Mechanism of action and therapeutic efficacy on cutaneous HSV-1 infection in mice. Antivir. Res. 2008, 80, 62-70. [CrossRef]

48. Likhitwitayawuid, K.; Sritularak, B.; Benchanak, K.; Lipipun, V.; Mathew, J.; Schinazi, R.F. Phenolics with antiviral activity from Millettia erythrocalyx and Artocarpus lakoocha. Nat. Prod. Res. 2005, 19, 177-182. [CrossRef]

49. Krawczyk, E.; Luczak, M.; Kniotek, M.; Nowaczyk, M. Cytotoxic, antiviral (in-vitro and in-vivo), immunomodulatory activity and influence on mitotic divisions of three taxol derivatives: 10 -deacetyl-baccatin III, methyl (N-benzoyl-( $\left.2^{\prime} \mathrm{R}, 3^{\prime} \mathrm{S}\right)-3^{\prime}$-phenylisoserinate) and N-benzoyl-(2'R,3'S)-3'-phenylisoserine. J. Pharm. Pharm. 2005, 57, 791-797. [CrossRef]

50. Kim, M.; Kim, S.K.; Park, B.N.; Lee, K.H.; Min, G.H.; Seoh, J.Y.; Park, C.G.; Hwang, E.S.; Cha, C.Y.; Kook, Y.H. Antiviral effects of 28-deacetylsendanin on herpes simplex virus-1 replication. Antivir. Res. 1999, 43, 103-112. [CrossRef]

51. Armaka, M.; Papanikolaou, E.; Sivropoulou, A.; Arsenakis, M. Antiviral properties of isoborneol, a potent inhibitor of herpes simplex virus type 1. Antivir. Res. 1999, 43, 79-92. [CrossRef]

52. Barquero, A.A.; Michelini, F.M.; Alché, L.E. 1-Cinnamoyl-3,11-dihydroxymeliacarpin is a natural bioactive compound with antiviral and nuclear factor-kappaB modulating properties. Biochem. Biophys. Res. Commun. 2006, 344, 955-962. [CrossRef]

53. Bueno, C.A.; Barquero, A.A.; Di Cónsoli, H.; Maier, M.S.; Alché, L.E. A natural tetranortriterpenoid with immunomodulating properties as a potential anti-HSV agent. Virus Res. 2009, 141, 47-54. [CrossRef]

54. Alché, L.E.; Assad Ferek, G.; Meo, M.; Coto, C.E.; Maier, M.S. An Antiviral Meliacarpin from Leaves of Melia azedarach L. Z. Für Nat. C 2003, 58, 215-219. [CrossRef] [PubMed]

55. Hayashi, K.; Hayashi, T.; Ujita, K.; Takaishi, Y. Characterization of antiviral activity of a sesquiterpene, triptofordin C-2. J. Antimicrob. Chemother. 1996, 37, 759-768. [CrossRef] [PubMed]

56. Hassan, S.T.S.; Šudomová, M.; Berchová-Bímová, K.; Šmejkal, K.; Echeverría, J. Psoromic Acid, a Lichen-Derived Molecule, Inhibits the Replication of HSV-1 and HSV-2, and Inactivates HSV-1 DNA Polymerase: Shedding Light on Antiherpetic Properties. Molecules 2019, 24, 2912. [CrossRef] [PubMed]

57. Nixon, B.; Stefanidou, M.; Mesquita, P.M.; Fakioglu, E.; Segarra, T.; Rohan, L.; Halford, W.; Palmer, K.E.; Herold, B.C. Griffithsin protects mice from genital herpes by preventing cell-to-cell spread. J. Virol. 2013, 87, 6257-6269. [CrossRef]

58. Torres, N.I.; Noll, K.S.; Xu, S.; Li, J.; Huang, Q.; Sinko, P.J.; Wachsman, M.B.; Chikindas, M.L. Safety, formulation, and in vitro antiviral activity of the antimicrobial peptide subtilosin against herpes simplex virus type 1. Probiotics Antimicrob. Proteins 2013, 5, 26-35. [CrossRef]

59. Quintana, V.M.; Torres, N.I.; Wachsman, M.B.; Sinko, P.J.; Castilla, V.; Chikindas, M. Antiherpes simplex virus type 2 activity of the antimicrobial peptide subtilosin. J. Appl. Microbiol. 2014, 117, 1253-1259. [CrossRef] [PubMed]

60. Huang, H.; Chan, H.; Wang, Y.Y.; Ouyang, D.Y.; Zheng, Y.T.; Tam, S.C. Trichosanthin suppresses the elevation of p38 MAPK, and Bcl-2 induced by HSV-1 infection in Vero cells. Life Sci. 2006, 79, 1287-1292. [CrossRef]

61. He, D.X.; Tam, S.C. Trichosanthin affects HSV-1 replication in Hep-2 cells. Biochem. Biophys. Res. Commun. 2010, 402, 670-675. [CrossRef]

62. Zheng, Y.T.; Chan, W.L.; Chan, P.; Huang, H.; Tam, S.C. Enhancement of the anti-herpetic effect of trichosanthin by acyclovir and interferon. FEBS Lett. 2001, 496, 139-142. [CrossRef]

63. Spear, P.G. Herpes simplex virus: Receptors and ligands for cell entry. Cell Microbiol. 2004, 6, 401-410. [CrossRef] [PubMed]

64. Däumer, M.P.; Schneider, B.; Giesen, D.M.; Aziz, S.; Kaiser, R.; Kupfer, B.; Schneweis, K.E.; Schneider-Mergener, J.; Reineke, U.; Matz, B.; et al. Characterisation of the epitope for a herpes simplex virus glycoprotein B-specific monoclonal antibody with high protective capacity. Med. Microbiol. Immunol. 2011, 200, 85-97. [CrossRef] [PubMed]

65. Patel, A.; Hanson, J.; McLean, T.I.; Olgiate, J.; Hilton, M.; Miller, W.E.; Bachenheimer, S.L. Herpes Simplex Virus Type 1 Induction of Persistent NF-кB Nuclear Translocation Increases the Efficiency of Virus Replication. Virology 1998, 247, 212-222. [CrossRef] 
66. Goodkin, M.L.; Ting, A.T.; Blaho, J.A. NF-кB Is Required for Apoptosis Prevention during Herpes Simplex Virus Type 1 Infection. J. Virol. 2003, 77, 7261-7280. [CrossRef] [PubMed]

67. Chiang, L.C.; Cheng, H.Y.; Liu, M.C.; Chiang, W.; Lin, C.C. In vitro anti-herpes simplex viruses and anti-adenoviruses activity of twelve traditionally used medicinal plants in Taiwan. Biol. Pharm. Bull. 2003, 26, 1600-1604. [CrossRef]

68. Vitali, D.; Bagri, P.; Wessels, J.M.; Arora, M.; Ganugula, R.; Parikh, A.; Mandur, T.; Felker, A.; Garg, S.; Kumar, M.N.V.R.; et al. Curcumin Can Decrease Tissue Inflammation and the Severity of HSV-2 Infection in the Female Reproductive Mucosa. Int. J. Mol. Sci. 2020, 21, 337. [CrossRef]

69. Cardozo, F.T.G.S.; Larsen, I.V.; Carballo, E.V.; Jose, G.; Stern, R.A.; Brummel, R.C.; Camelini, C.M.; Rossi, M.J.; Simões, C.M.O.; Brandt, C.R. In VivoAnti-Herpes Simplex Virus Activity of a Sulfated Derivative of Agaricus brasiliensis Mycelial Polysaccharide. Antimicrob. Agents Chemother. 2013, 57, 2541-2549. [CrossRef]

70. Petrera, E.; Coto, C.E. Therapeutic effect of meliacine, an antiviral derived from Melia azedarach L.; in mice genital herpetic infection. Phytother. Res. 2009, 23, 1771-1777. [CrossRef]

71. Alché, L.E.; Berra, A.; Veloso, M.J.; Coto, C.E. Treatment with meliacine, a plant derived antiviral, prevents the development of herpetic stromal keratitis in mice. J. Med. Virol. 2000, 61, 474-480. [CrossRef] 